\title{
The EfFectiveness Of The Collaborative Learning Model ON Trigonometry TOPIC OF SENIOR HIGH SCHOOL STUDENT GRADUATE $X$ USING OPEN-ENDED APPROACH
}

\author{
Nurhayati $^{1)}$, Karyati $^{2}$ \\ ${ }^{1)}$ STKIP Singkawang, Singkawang, Indonesia \\ E-mail: murhavati(astkipsingkawang.ac.id \\ ${ }^{2)}$ Universitas Negeri Yogyakarta, Yogyakarta, Indonesia \\ E-mail: karvati@umvacid
}

\begin{abstract}
This study aimed to describe the effectiveness of collaborative learning using open-ended approach and openended approach in terms of problem solving skillss students. This study is a quasi-experimental research with the entire population of ten graduate science students of SMA Negeri 2 Ngaglik, Sleman, Yogyakarta which consists of four classes. The research samples were randomly selected from the four existing classes, in order to obtain class X MIPA 3 to be given collaborative learning model using open-ended approach and class X MIPA 1 to be given open-ended approach. Data analysis technique consists of one sample t-test used to investigate the effectiveness of collaborative learning model using open-ended approach and open-ended approach. The results show that collaborative learning model using open-ended approach is effective in terms of student's problem solving skillss of SMA Negeri 2 Ngaglik, Sleman, Yogyakarta. But, open-ended approach isn't effective in terms of student's problem solving skillss of SMA Negeri 2 Ngaglik, Sleman, Yogyakarta.
\end{abstract}

Keywords: collaborative, open-ended

\section{INTRODUCTION}

In Indonesia Education, there are a variety of learning objectives to be achieved. Learning objectives to be achieved are set forth in the regulations of government. In Permendikbud No. 103 Tahun 2014 on Education in Primary and Secondary Education, stated that there are a wide variety of learning principles. Some of the principles formulated learning that learners are facilitated to find out, learning that emphasizes the divergent answers that have a multidimensional truth and competency-based learning [1]. As for some of the competencies that should be owned by the students of class X based Permendikbud No. 64 Tahun 2013 on the Content Standards for Primary and Secondary Education, namely: (1) have a curiosity, confidence and interest in mathematics; and (2) shows the attitude logical, critical, analytical, creative, meticulous, responsible, responsive and does not easily give in solving the problem [2].

In general, student achievement are used to measure the achievement of a learning objective. According to Collins \& O'Brien [3], student achievement can help teachers determine the extent of their knowledge of a student or know the extent of achievement of learning goals that have been formulated. Based on the 1 earning objectives have been disclosed previously, the learning geared to empower all learners be expected competencies, one of which is the problem solving skills of students.

Lesh \& Doerr [4] states that the activity is defined as the skill of solving a problem that promote the improvement of the thinking of students included in the resolution. The process of thinking in solving this problem it is important to be imparted to the students so that the students get used to resolve problems that occur in their life.

But in fact, the condition happens on the pitch is not in accordance with the desired conditions. Learning in school is focused on a single answer. This is in line with that expressed by Becker \& Shimada [5], namely learning problems in school mathematics is dominated by the answer to one procedure or one correct answer. Moreover, learning in school is also still apply the students were told, this is in line with research conducted by Bjork [6] who get the result that Indonesia still apply learning in teacher centered.

Field data also shows that the ability of the settlement of the problem is not in accordance with the conditions expected. In addition, based on interviews with one of the teachers at SMAN 2 Ngaglik, Sleman, Yogyakarta which was held on October $30^{\text {th }}$, 2015 showed that the model of collaborative learning with open-ended approach and openended approach was never done by the teacher. Then, problem solving skills is also observed by the teacher. Teachers do not pay attention to problem solving skills of students during the learning takes place. 
If the reality on the ground is not addressed, then the learning objectives have been formulated can not be achieved. Therefore, so that the learning objectives can be achieved, performed a variety of solutions. One solution offered by the researchers are using a collaborative learning model with an open-ended approach.

According to Laal \& Laal [7], collaborative learning is learning which involves grouping students to work together to solve a problem, task or manufacture of a product. Students in the group to decide and look for themselves how they are in solving the problem, a task or a product without direct referrals from teachers. Therefore, the freedom given in collaborative learning really emphasize contribution from student in completing a common task. According to Jones, Rasmussen, \& Moffitt [8] interactions toward peers, teachers, friends groups and experts can develop communication and problem solving skills. Mourtos, Okamoto, and Rhee [9] states that the first step in developing the problem solving skills is to adopt the methodology of the open-ended approach. Correspondingly, according to the results of research conducted by several researchers get the result that the open-ended approach is effective in terms of problem-solving skills of students (e.g. [10]-[11]). As for Becker \& Shimada [5] expressing opinion about the open-ended approach. According to them openended approach is a way of learning with the settlement of a problem given that the truth answer emphasized the multidimensional, providing experience in getting something new in the process of resolving a given problem. Learning with open-ended approach will work well if done in a group. This is due to the characteristics of this approach is the need of construction of various types of ideas, so it would be more effective if students learn in groups.

Based on the description that has been said, we can conclude that there is a gap between what is desired with what is happening in the field. Some of the learning principles stated in Permendikbud No. 103 Tahun 2014 was facilitated learners to find out, learning that emphasizes the divergent answers that have a multi-dimensional truth and competency-based learning. However, based on research conducted by some experts to get the results of that learning in school is still using teacher centered and still emphasize single answer, besides teaching in schools also has not noticed the problem solving skills of the students. This is not a direct impact on student achievement, problem solving skills and confidence of students. Therefore, researchers feel the need to conduct research on "The Effectiveness Of The Collaborative Learning Model On Trigonometry Topic Of Senior High School Students Graduate X Using Open-Ended Approach In Terms from Problem solving skills Students".

\section{METHOD}

This research is a quasi-experimental research with a pretest-posttest design nonequivalent group design. This research was conducted at SMAN 2 Ngaglik, Sleman, Yogyakarta. When the study took place from February $2^{\text {th }}$, 2016 until March 26 ${ }^{\text {th }}, 2016$. The population in this study were all students of class X MIPA SMAN 2 Ngaglik, Sleman, Yogyakarta, academic year 2015/2016 consisting of four parallel classes. The study sample was randomly selected from four classes, in order to obtain class X MIPA 3 applied a model of collaborative learning with open-ended approach and X MIPA 1 applied open-ended approach.

There are two variables in this study, namely the independent variable is learning, which consists of two levels are collaborative learning model with open-ended approach and open-ended approach; and one dependent variable is the skills of the student problem solving. There are four stages in a collaborative learning model with openended approach that formulate, share, listen and create. Then, there are two periods in the open-ended approach, namely the first period and the second period. There are five indicators on aspects of problem solving skills, are understanding the problems, plan solutions, propose solutions, evaluate solutions and implementation of solutions. The research instrument used is the test instrument in the form of problem solving skills test and observation sheet form lesson observation sheet. As for the problem solving skills test that consists of 3 problems descriptions used to measure problem solving skills of students. While lesson observation sheets made up of several indicators that show the student activity and teacher activity in the learning process is used to determine the percentage of learning collaborative learning model approach open-ended and open-ended approach.

The validity of this research is to test the validity of the contents of students' problem-solving skills. Then, to estimate the reliability of the instrument is done by finding the coefficient of reliability by using the formula coefficient alpha $(\alpha)$ to test problem solving skills (pre-test and posttest).

The analysis was performed using SPSS 21. The results show that the reliability coefficient (coefficient alpha) to pretest the skills of problem solving and post-test students' problem solving skills are respectively 0.737 and 0.697 . SEM calculation is done with the help of Microsoft Office Excel 2013. The calculation results for the pre-test problem solving skills and post-test students' problem solving skills are respectively 8.546 and 8.423 .

Data collection techniques starts with the provision of problem solving skills test (pre-test) prior to treatment of both classes were selected as sample. The next stage is the provision of treatment which is the application of collaborative learning model with an open-ended approach to the experimental class (class X MIPA 3) and open-ended approach to the control group (X MIPA 1). The next stage is the provision of problem solving skills test (post-test) students after the treatment of the two classes. Data analysis techniques in this study is a description of the data and inferential analysis. Description of the data is made to all the variables by analyzing the size of the centralization of data aimed at finding the average deployment size while analysis was conducted in order to find the minimum score and maximum score, both for the data before and after treatment. Meanwhile inferential analysis is performed with assumption 
test, test and test the effectiveness of the effectiveness differences.

To test the effectiveness of collaborative learning model with open-ended approach and open-ended approach in terms of the skills of students to use problem-solving test one sample t-test with the following formula [12]:

$$
t=\frac{\bar{x}-\mu_{0}}{\frac{s}{\sqrt{n}}}
$$

$\bar{x}$ is the average value obtained, $\mu$ is the average value of the hypothetical, $\mathrm{S}$ is the sample standard deviation and $\mathrm{n}$ is the many members of the sample. The criteria for the effectiveness of problem solving abilities seen from the average score of the class that has been set is 60 , which the collaborative learning model with open-ended approach and open-ended approach is said to be effective when the value of the average grade obtained by students over 60 .

In the inferential analysis, prior to the ANOVA test, first tested the assumption that the test for normality and homogeneity test. Normality test is performed to determine whether the sample data comes from a normal distributed population, both for the data before and after treatment includes data problem solving skills of students from both classes. The normality test is meant is univariate normality.

For univariate normality test was done using the Kolmogorov-Smirnov test to the data after treatment with SPSS 21 and at a significance level of 5\%, the data is said to be distributed univariate normality if the significance value greater than 0.05. Based on the calculation, KolmogorovSmirnov significant value to the data problem solving skills in classes that implement collaborative learning model with the open-ended approach is 0.654 . While in the class that implements the open-ended approach significance value to the data capability for problem solving is 0.802 . Based on these results, it can be said that the normality assumption for univariate data after treatment, the class that implements the model of collaborative learning approach to open-ended and open-ended approach has been to meet the assumptions of normality in univariate.

Furthermore, the homogeneity test in this study aimed to see whether the two experimental groups homogeneous or not. This test is performed through Lavene Statistic test using SPSS 21. The decision criterion used is the data is said to meet the assumption of homogeneity univariate if the significance value that is greater than 0.05. Based on the calculations, Lavene Statistic significance values for the data before and after treatment were greater than 0.05 is 0.855 to 0.541 data before treatment and after treatment for the data. This means that the problem solving skills of students in both classes, before and after the treatment is the same or homogeneous.

After the test assumptions are met, then the subsequent analysis is hypothesis testing to answer the problem formulation. The data analyzed in this section are the data before and after treatment. Analysis of the data before the treatment was intended to see whether there are differences between the two classes before the treatment and analysis of data after the treatment was intended to see whether there are differences in effectiveness between the two classes after being given treatment.

It is said there is a difference between the effectiveness of collaborative learning model with open-ended approach and open-ended approach in terms of problem-solving skills of students to data before treatment and after treatment of data if the significance value less than 0.05 .

Furthermore, after finding out that there is a difference between the two classes (classes that implement collaborative learning model with open-ended approach and the class that implements the open-ended approach), then tested as to which is more effective learning. Statistical tests were used to test the three hypotheses above are univariate $(\mathrm{t})$ using Bonferroni criteria or t-Bonferroni. The formula for the test statistic is [13]:

$$
t=\frac{\bar{y}_{1}-\bar{y}_{2}}{\sqrt{\frac{\left(n_{1}-1\right) S_{1}^{2}+\left(n_{2}-1\right) S_{2}^{2}}{n_{1}+n_{2}-2}\left(\frac{1}{n_{1}}+\frac{1}{n_{2}}\right)}}
$$

dengan:

$$
\begin{aligned}
& \bar{y}_{1}=\text { average value of sample I } \\
& \bar{y}_{2}=\text { average value of sample II } \\
& S_{1}^{2}=\text { variance sample I } \\
& S_{2}^{2}=\text { variance sample II } \\
& n_{1}=\text { many members of the sample I } \\
& n_{2}=\text { many members of the sample II } \\
& p=\text { number of variable dependent }
\end{aligned}
$$

Criterion statistical testing for the above test is $\mathrm{H}_{0}$ if $t_{\text {hit }} \geq t_{\left(\frac{\alpha}{p} ; n 1+n 2-2\right) \text {. }}$

\section{RESULT AND DISCUSSION}

\section{A. Results}

The data described in this study is the test data problem solving skills of students in both classes, for both data before and after treatment. Data described for problem solving skills include a data problem solving skills test scores before and after treatment consisting of the average, maximum theoretical value, the theoretical minimum value, maximum value and minimum value, standard deviation and variance. Brief description of good data for classes that implement of collaborative learning model with open-ended approach and open-ended approach before and after treatment can be seen in TABLE I.

TABLE I. Data Description Problem Solving Skills Before and After Treatment

\begin{tabular}{lllll}
\hline Description & \multicolumn{2}{c}{$\begin{array}{c}\text { Collaborative Open- } \\
\text { Ended Class }\end{array}$} & \multicolumn{2}{c}{ Open-Ended Class } \\
& Before & \multicolumn{1}{c}{ After } & Before & After \\
\hline Average & 7,23 & 65,29 & 9,79 & 61,62 \\
Max Theoretical & 100 & 100 & 100 & 100 \\
Min Theoretical & 0 & 0 & 0 & 0 \\
Max Value & 36,36 & 90,9 & 33 & 87,88 \\
Min Value & 0 & 42,4 & 0 & 33,33 \\
St. Dev & 11,36 & 11,965 & 10,67 & 12,94 \\
\hline
\end{tabular}


Based on TABLE I, can be obtained information that the average value of problem solving skills before treatment has not reached the average value of 60 is 7.23 for the class that implements of collaborative learning model with open-ended approach and 9.79 for classes that implement open-ended approach. Meanwhile, after being treated well in classes that implement collaborative learning model with open-ended approach and the class that implements the open-ended approach has reached an average value above 60 is 65.29 and 61.62 .

Test the effectiveness of collaborative learning model with open-ended approach and open-ended approach aims to determine the effectiveness of collaborative learning model with open-ended approach and open-ended approach in terms of problem-solving skill of students. After calculation by using SPSS 21 problem-solving skills to the data obtained $\mathrm{t}$ value and significance as in TABLE II.

TABLE II. Test Results One Sample t-test

\begin{tabular}{|c|c|c|c|c|}
\hline \multirow[t]{2}{*}{ Aspect } & \multicolumn{2}{|c|}{$\begin{array}{c}\text { Collaborative } \\
\text { Open-Ended } \\
\text { Class }\end{array}$} & \multicolumn{2}{|c|}{$\begin{array}{l}\text { Open-Ended } \\
\text { Class }\end{array}$} \\
\hline & $t$ & Sig. & $t$ & Sig. \\
\hline Problem Solving Skills & 2,466 & 0,020 & 0,684 & 0,499 \\
\hline
\end{tabular}

Based on TABLE II, there was information that the significant value of $t$ for second grade if halved in value less than 0.05. In addition, information was obtained that $t$ is positive for collaborative open-ended class. This means that the model of collaborative learning with open-ended approach is effective in terms of problem-solving skills of students. Then, there was information that $t$ is positive for the open-ended class. This resulted in H0, which means that the open-ended approach is not effective in terms of problem-solving skills of students. Hypothesis test done next is to test whether there are differences between the effectiveness of collaborative learning model with open-ended approach and open-ended approach to the data before and after treatment. After calculation by using SPSS 21 to the data problem solving skills before and after treatment, the result as shown in TABLE III.

TABLE III. Results of ANOVA Test Before and After Treatment

\begin{tabular}{lcc}
\hline & $\boldsymbol{F}$ & Sig. \\
\hline Data before treatment & 0,825 & 0,367 \\
Data after treatment & 1,333 & 0,253 \\
\hline
\end{tabular}

Based on TABLE 3 shows that the significant value of $F$ obtained for the data before and after treatment, respectively, are 0.367 and 0.253 that is greater than 0.05 to data before treatment and after treatment of data. This means that before treatment and after treatment there was no difference between the students problem solving skills of the two classes.

\section{B. Discussion}

In this study, there are three research hypothesis, based on the results of hypothesis testing, there is a hypothesis in this study were met and that the model of collaborative learning with open-ended approach is effective in terms of problem-solving skills of students. There are two hypotheses are not met in this study are (1) approaches the open-ended ineffective in terms of the skill to solve the problem and (2) collaborative learning model with open-ended approach more effective than the open-ended approach in terms of student's problem solving skills. To facilitate discussion, in this section will be described one by one third related hypotheses in this study. The detailed discussion is as follows.

\section{1) Effectiveness Collaborative Learning Model With Open-Ended Approach}

The results of this study indicate that collaborative learning model with open-ended approach is effective in terms of problem-solving skills of students. Based on the hypothesis test result obtained information that the value of one sample t-test for the hypothesis of the effectiveness of collaborative learning model with open-ended approach in terms of problem-solving skills (TABLE 2) amounted to 2.466 with significance of 0.010 . This means that collaborative learning model with open-ended approach is effective in terms of problem-solving skills.

The effectiveness of collaborative learning model with open-ended approach is effective in terms of problemsolving skills of students due to student collaboration in solving the problem of finding the conclusion is of considerable concern. Student collaboration that has resulted in the incorporation of ideas, possible answers and solutions provided by each student in the group to resolve the issue. This means, the group's work obtained an amalgamation of thinking of each member of the group. As a result, it is much easier for students to provide solutions to questions or instructions on students' worksheets. This is in line with that expressed by Clifford [14], which revealed that the "Mixed groups that include a range of talents, backgrounds, learning syles, ideas, and experiences are best. Studies have found that mixed groups growing niche aptitude to learn more from each other and increase of the achievement of low performers. "Heterogeneous group composed of the different levels of abilities, backgrounds, learning styles, ideas, and experience is the best. Students studying in heterogeneous groups can improve students' mathematics learning achievement results. In addition, activity in collaborative learning model with open-ended approach also shows that the students are involved from the beginning until the end of the lesson learning. This is the reason why collaborative 
learning model with open-ended approach is effective in terms of problem-solving skill of students.

\section{2) The Effectiveness of the Open-Ended Approach}

The results of this study indicate that the open-ended approach is not effective in terms of problem-solving skills of students. Based on the hypothesis test result obtained information that the value of one sample t-test for the hypothesis of the effectiveness of open-ended approach in terms of problem-solving skills (TABLE 2) is equal to 0.684 with a significance of 0.2495 . This means that the openended approach is not effective in terms of problem-solving skill.

Ineffectiveness of open-ended approach is not effective in terms of problem-solving skills is due to the problemsolving process open-ended approach does not involve the incorporation of students' thinking. The group was formed in the open-ended approach does not consist of a heterogeneous student. The formation of the group carried out solely by the student. Students in the group tend to have the same thought. So little thought differences occur in solving problems given to students' worksheets. This resulted in less students construct knowledge in depth so the impact on mathematics achievement. This is the reason why the open-ended approach is not effective from the aspect of problem solving skills of students.

\section{CONCLUSIONS AND SUGESTION}

\section{A. Conclusions}

Based on the findings and discussions that have been described, it can be concluded several things: collaborative learning model with open-ended approach is effective in terms of problem-solving skills of students and open-ended approach is not effective in terms of problem-solving skills of students.

\section{B. Suggestion}

Based on the conclusions obtained then there are some suggestions that can researchers provide model-related learning and learning approach used in this study, namely: holding overhaul of the group based on the level of cognitive and sex of the student, give rewards to students to be motivated to produce creative ideas good in asking questions or solutions or settlement. Then for the next researcher is advised to carry out studies that tested the effectiveness of collaborative learning model with open-ended approach on a review of the different aspects and more, which is not limited to the skills of solving problems of students so that they can provide more information related to the effectiveness of the collaborative learning model with openended approach.

\section{ACKNOWLEDGMENT}

We would like to thank ADRI which provides template to help all participants writes a journal easily and conducts this international seminar. We would like to thank to STKIP
Singkawang which fund all of cost to present this research and some lecturers who give advices to make better idea in this research. Without all of people who support this research, we cannot write this research well and properly.

\section{REFERENCES}

[1] Mendikbud, "Peraturan Menteri Pendidikan dan Kebudayaan Republik Indonesia Nomor 103 Tahun 2014, tentang Pembelajaran pada Pendidikan Dasar dan Pendidikan Menengah”, 2014.

[2] Mendikbud, "Peraturan Menteri Pendidikan dan Kebudayaan Republik Indonesia Nomor 64 Tahun 2013, tentang Standar Isi Pendidikan Dasar dan Menengah", 2013.

[3] Collins, J.W. and O'Brien, N.P, "The greenwood dictionary of education", London: Greenwood Press, 2003, p.4.

[4] Lesh, R. and Doerr, H.M, "Beyond constructivism: models and modeling perspectives on mathematics problem solving, learning, and teaching", Mahwah: Lawrence Erlbaum Associates, Inc. 2003, p.319.

[5] Becker J. P. and Shimada, S, "The open ended approach: a new proposal for teaching mathematics", Reston, Virginia: NCTM, 2005.

[6] Bjork, C, "Indonesian education: teachers, schools, and central bureaucracy", New York and London: Routledge, 2005.

[7] Laal, M and Laal, M, "Collaborative learning: what is it?" ProcediaSocial and Behavioral Sciences, 2011, vol. 31, pp. $491-495$.

[8] Jones, B. F., Rasmussen, C.M., and Moffitt, M.C, "Real-life problem solving: a collaborative approach to interdisciplinary learning", Washington: American Psychological Association, 1997, p. 21

[9] Mourtos, N.J., Okamoto, N.D., and Rhee, J, "Defining, teaching, and assessing problem solving skills" this paper published on $7^{\text {th }}$ UICEE Annual Conference on Engineering Education, in Mumbai, India, 2004, p.2.

[10] Melianingsih, N., \& Sugiman, S. (2015). KEEFEKTIFAN PENDEKATAN OPEN-ENDED DAN PROBLEM SOLVING PADA PEMBELAJARAN BANGUN RUANG SISI DATAR DI SMP. Jurnal Riset Pendidikan Matematika, 2(2), 211 - 223. doi: http://dx.doi.org/10.21831/jrpm. v2i2.7335

[11] Subekti, S. (2016). Komparasi Keefektifan Pendekatan Open-Ended dan GI Ditinjau dari Komunikasi, Pemecahan Masalah Matematis dan Motivasi Belajar. PYTHAGORAS: Jurnal Pendidikan $\begin{array}{lrlr}\text { Matematika, } & 8(2), & 204-212\end{array}$ doi:http://dx.doi.org/10.21831/pg.v8i2.8950

[12] Weiss, N.A, "Introductory statistics $9^{\text {th }}$ ed" Boston: Pearson, 2012 p.344.

[13] Stevens, J. P, "Applied multivariate statistics for the social sciences(5 $5^{\text {th }}$ ed.)", New York, NY: Routledge, 2009, p.147.

[14] Clifford, M, "Facilitating collaborative learning: 20 things you need to know from the pros". [Online] Available:http://www.opencolleges.edu.au/informed/features/facilitat ing-collaborative-learning-20-things-you-need-to-know-from-thepros/, 2012 